\title{
One City; Two Conditions: Exigent Parameters for Paint Performance in Lagos, Nigeria
}

\author{
FOLORUNSO, CLEMENT OLUWOLE ${ }^{1}$ and MOHD HAMDAN BIN AHMAD ${ }^{2}$ \\ 1) Folorunso Clement Oluwole is currently a $\mathrm{PhD}$ candidate in the Department of Architecture, Universiti \\ Teknologi Malaysia (UTM) and the corresponding author through- cleoconsult2@yahoo.co.uk or \\ olajope@yahoo.com. \\ 2) Mohd Hamdan Bin Ahmad is a Professor of Architecture, Universiti Teknologi Malaysia (UTM). Currently, \\ He is the Executive Director of Institute Sultan Iskandar of the University
}

\begin{abstract}
Tropical buildings are subjected to many militating elements of climate, prominent among which are insolation and rainfall. However, the study area has an additional influence from the Atlantic Ocean which is just a few meters away from the buildings. The sea breeze is laden with high salt content which has adverse effects and reactions on the materials used for building finishes. The outer skin-external surface of any building does not have any protection in most cases due to its function as the protective layer. However, the influence of this prevalent saline air differs from one part of the study area to another due to distance. The study bifurcated the city through a survey approach into two zones A\&B to obtain data for empirical analysis. Various correlations were drawn while regression analysis was carried out. The means of the two zones were determined through ANOVA to establish the performance of paint in service in the two locations. Frequencies and all the analysis were run through SPSS version 15.0 for the study. Data was also obtained from practicing Architects in Lagos through a structured interview. It shows that depreciation of paint sets in faster and repainting is required earlier in Zone A than Zone B due to more aggressive impact of saline air. The established research findings that stipulate 5-7years for maintenance of paint does not hold in areas subjected to saline air. The research is geared towards establishing the appropriateness of the use of paint in a saline laden environment when compared with other parts of the tropical region. Specifiers/architects, developers and property owners are hereby educated on the implication of their choice. Manufacturers are equally advised to develop paint that will retard the effect of saline air the more. This study is the first attempt to analytically investigate the impact of saline air on the maintenance requirement of paint in the tropical region.
\end{abstract}

Keywords: Atlantic Ocean; external finishes; climate; frequency; impact; maintenance; paint; performance; saline air; salt

\subsection{INTRODUCTION}

One of the factors that are responsible for regular maintenance requirement of building exterior is the climate (Butt et al, 2010). The environment that accommodates a building plays a prominent role in the life cycle of the building. Though other factors such as: materials used, methods of construction, the volume or frequency of usage, quality of materials to mention a few contribute largely to the maintenance demand of interior spaces, the exterior surface is majorly affected by the interplay of weather elements. Most of the major cities and conurbations of the world exist under similar pattern of weather such as rainfall and sunshine.

However, in areas within the same conurbation that are at close distance to the ocean, humidity and wind speed is higher while temperature is lower during the day and higher at night due to the effect of land and sea breeze. The continuous action of ocean wave along the coaster region increases humidity and its contents, majorly the salt from the sea through evapo-transportation which (Kaufman, 2003) submit is very high. In chemical and physical oceanography Oyewo et al (1982) and Folorunsho (2004) submit that sea spray increases from the sea when there are surges. They discovered that the Atlantic Ocean around the study area experiences both the low tides and high tides daily. This in their findings brings and releases more salt into the area.

Oyewo et al (1982) affirm that the quantity of atmospheric salt increase more during dry season. The oceans around the world contain salt (Bates, 2002; kaufman, 2003; Zahn, 2007; David 2008) "The saline rate (the salt content of the sea) on the average for seawater in the world's oceans has a salt content of about 3.5\% (35 $\mathrm{g} / \mathrm{L}$, or $599 \mathrm{mM}$ ). This implies that in every kilogram (about one litre by volume) of seawater, there is an average of 35 grams (1.2 oz) of dissolved salts". Adepelumi et al (2009) discovered that the Atlantic Ocean has a high concentration of salt; this was also reported by Corvo et al (2010).

The quantity of atmospheric salt decreases as it moves farther away from the sea because of buildings and vegetal cover that serve as buffers. While the vegetal cover feel the impact of the salt (Baltrenas et al, 2006) the buildings feel the pain. Buildings sited at close distance to the sea are affected and depreciated by varying degrees of salt deterioration (Butch, 2008) Prominent among the components of building that feel the pain of salt spray is the external finish, though contact of any form with salt has being confirmed to pose serious danger to the entire structure as it affects building materials negatively (Costa \& Appleton, 1999; Ahl, 2004; Sawdy and Heritage, 2007; Gonclaves et al, 2009; Corvo et al, 2010) 
The most commonly used material for external building finishes for residential buildings is paint. Several researches have concluded that salt impact paint negatively (Roy et al, 1995; Morcillo, 1999; Malshe and Waghoo, 2004; Goncalves et al, 2009; Komshin, 2010; Anderson et al, 2011). This paper examines the impact of salt on paint and its effect on the frequency of maintenance of external surface of buildings in Lagos, Nigeria. It also critically observed through survey how distance away from the ocean affect the rate of failure and changes the frequency of maintenance.

\subsection{SALT ATTACK ON PAINT}

A salt compound occurs when one or more hydrogen atoms of an acid are replaced by one or more cations of the base. The most common which is also from the ocean majorly is sodium chloride and sulfate from different sources. Salt forms crystals after its deposition on wall surfaces through the action of climate. Crystallization pressure is capable of producing higher tensile stress on paint. AbuBakar et al (2011) agree that salt crystallization is sufficient to damage painted walls and the entire masonry structure.

External walls finishes that are exposed to aggressive environment like the coastal area, are subjected to degradation. Salt as a contaminant can alter the performance of paint both chemically and physically (Vanhees et al, 2009; Zhang et al, 2011). Its influence on the painted wall is either through the substrates during construction or and through absorption from the atmosphere or capillarity during the service life of the building.

The major source of salt attack is through the salt laden air from the sea (AbuBakar et al, 2011) which mixes with moisture, humid air and underground water (Adepelumi et al, 2009). Other sources of salt attack on building materials have been identified by Young (1995) some of which include saline soil/sand, groundwater, sea spray, air pollutants, air-borne salt and the use of salt water in the mixing of concrete, mortar and paint.

Sand quarried from the sea which is the major source of sand for building construction in Lagos, Nigeria contribute largely to salt induced degradation of substrate which has effects on the paint in-service (Mukhopadhyaya, 2011). The prevalence of high humidity aids the degradation processes. Navarro and Doehne (1999) for instance opined that sodium sulfate and sodium chloride activate more reaction on walls in relatively humid environment.

Salt causes the disintegration of the microstructure of paint, binding effect, spalling and cohesion (AbuBakar, 2011) and when crystallization takes place at substrate surface or within paint film, this may cause sufficient deterioration of paint due to hydration pressure, linear crystal growth and hydrostatic pressure arising from continuous salt build up on the surface of external walls (Scherer, 2004). It leads to durability problems either directly through crystallization or hygroscopicity or indirectly through the catalyst role of salt chemical reactions. The presence of salt attack leads to expansion of mortar chemically which could later result in external wall expansion that will cause cracks in paint films.

Salt weathering process does not only affect the painted wall, it goes on to impact negatively on the substrates either at the surface of the render or within the plaster. Salt attack on the inside comes through salt laden moisture transfer inside the wall- rising damp, leakage, all means of water contact and salt contamination of materials like sand from the sea used in the construction of the building. It occurs on the surface through saltspray from the ocean, air pollution and humid air. The damage is usually gradual from the surface inform of peeling of paint, chalking and eventual collapse of the finish system (Groot et al, 2009). The accumulation of salt within render is responsible for defects such as spalling-breaking into flakes of cement renders.

Salt build-up in render (substrate) is caused by changes in porosity of render layers, application of water repellent additives, occurrence of a drying front within the render and the presence of gap or void at the interface between the paint film and the rendered substrate. This is due to poor application technique or loss of adhesion caused by high shrinkage aided by moisture. The source through which moisture builds up include: rising damp in wall from a continuous source such as ground water level/content, rain, fog, moisture spray, condensation, humidity, cleaning processes and occasional sources like leakages from plumbing pipes and flooding. The rate of absorption of moisture in building is higher on the exterior wall than the interior due to direct contact with the environment. The rate and impact of damage caused by salt is subject to the concentration or its accumulation at specific location on the wall (Groot et al, 2009). The quantity of salt that is impacted at a point by moisture and the precipitation condition aggravate deterioration faster. The type of salt in action also determines the type and impact of failure.

However, the presence of salt on a substrate does not trigger deterioration until the action of water or moisture is involved which serves as agent of distribution. The concentration at local point does more damage than the general distribution that reduces concentration at a point. Local concentration aids repeated crystallization which is majorly responsible for defects in building materials. The flow and distribution of salt through moisture in external wall and paint film is dependent according to Folorunso (2010) on environmental condition-the drying process apart from the influence of the properties of the substrate and the type of paint used.

Groot et al (2009) observed that intensive sunlight, strong wind and ventilation may result into a high drying process of moisture from substrate which may result in a drying front within the render. This may 
consequently lead to spalling due to crystallization and precipitation. Environmental condition therefore, is a factor to be considered when selecting paint for a particular substrate. Wrong choice of paint will influence earlier defects and the types of defects in rendered wall.

Crystallization of salt in building materials have been examined through various theories (Vanhees et al, 2009). Wellman and Wilson (1965) opined that large crystals will grow first in large pore at the expense of small crystals in small pores. However, Navarro and Doeline (1999) disagree with this theory stating otherwise that salt would crystallize in the smaller pores earlier than bigger pores. The obvious from the theories is that salt crystallization takes place in the pores within building materials which causes a lot of damage that raise concern for maintenance. These damages are mostly irreversible when they occur as new materials have to be sourced for repair and restoration.

\subsection{STUDY AREA}

The study area chosen for this research is Lagos, the most populous city in Africa. Being a conurbation, it covers an area of 3,577sq.km representing 0.4 percent of Nigeria territorial land mass (Esubiyi, 1994). The Crown Colony was created by the British in 1861. The administration of Lagos preceded the formation of Nigeria in 1914. It is the largest city located on the Atlantic Ocean around the world. With a population of over 17 million, a state within the Federation with twenty (20) Local Government Areas, it is a human habitat location that requires attention. The geographical location is between latitude $6^{\circ} 27^{\prime}$ and $6^{\circ} 45^{\prime}$ North of the Equator and on longitude $3^{\circ} 20^{\prime}$ and $3^{\circ} 39^{\prime}$ East of the Greenwich Meridian. Parts of the study area are just about 200meters away from the Atlantic Ocean. This explains the succeptability of the buildings external finishes to direct saline air from the Ocean.

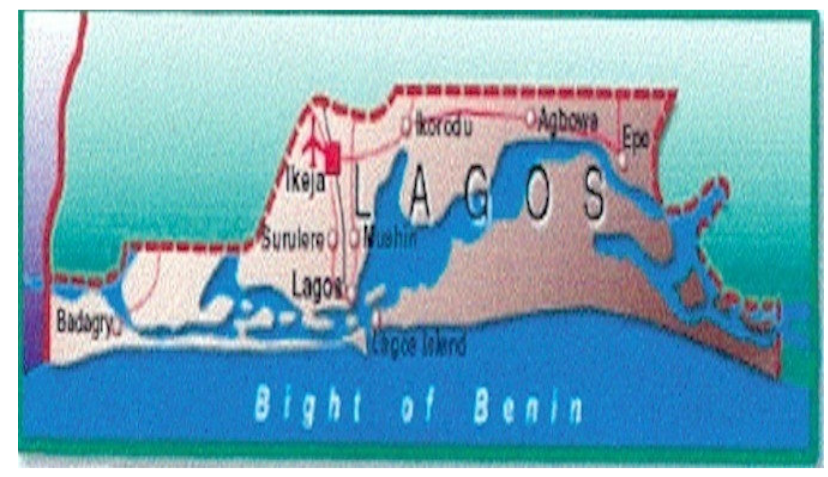

\subsection{RESEARCH METHODOLOGY}

The procedure adopted for the study is the multi-stage sampling technique for the first target population from the two zones into which the study area was divided. The primary stage of division was a deliberate bifurcation of the study area into two. This was done by selecting all the Local Government Areas (LGAs) that have direct contact with the Atlantic Ocean through non-random selection. These are designated as Zone $\boldsymbol{A}$-Sea side. All the Local Government Areas that do not have direct contact with the Atlantic Ocean were also selected through a non probability sampling. These are designated as Zone $\boldsymbol{B}$ - Hinterland.

This non-probability sampling which is also referred to as deliberate sampling, judgment sampling, convenience sampling and purposive sampling according to Creswell (2012), Leedy and Ormrod (2010) are supreme decisions taken by the researcher, the decisions are sacrosanct. The second stage was carried out through random selection of Local Governments in each Zone. Further random selection was done in selecting enumeration areas and sample units for the administration of questionnaires within each Zone.

There are twenty (20) LGAs in Lagos as earlier mentioned. Ten (10) are located at close proximity to the Atlantic Ocean-Zone A while the remaining 10 are at hinterland. As shown with red line in Figure2 below. Figure2: Map of Lagos showing the 20 Local Governments. Source: Aluko, 2010 


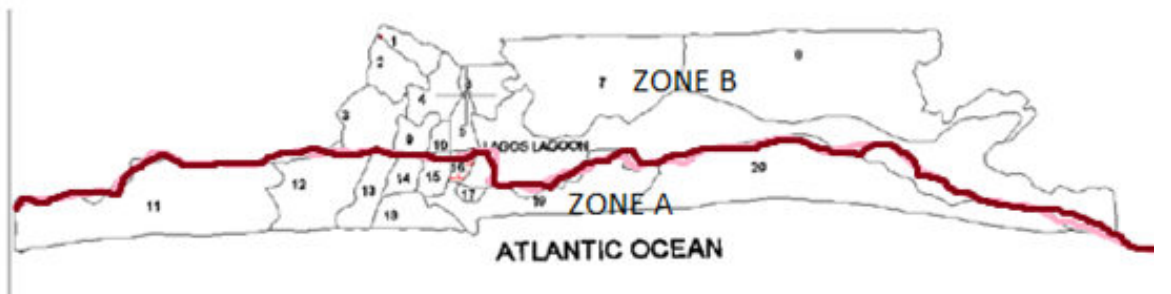

1-Agege 2-Ifako. Ijaye 3-Alimosho 4-Ikeja 5-Shomolu 6-Koshofe 7-Ikorodu 8-Epe 9-Oshodi- Isolo 10. Mushin 11-Badagry 12- Ojo 13.Amuwo Odofin 14-Ajeromi Ifelodun 15. Surulere 16-Lagos Mainland 17.Lagos Island18-Apapa 19-Eri Osa 20-lbeju-Ledki Source: Lagos State Map, 2010

Figure 3: Selected LGAs. Source: Researcher's field work (2012)

Map of Lagos State showing the 20 Local Govemments

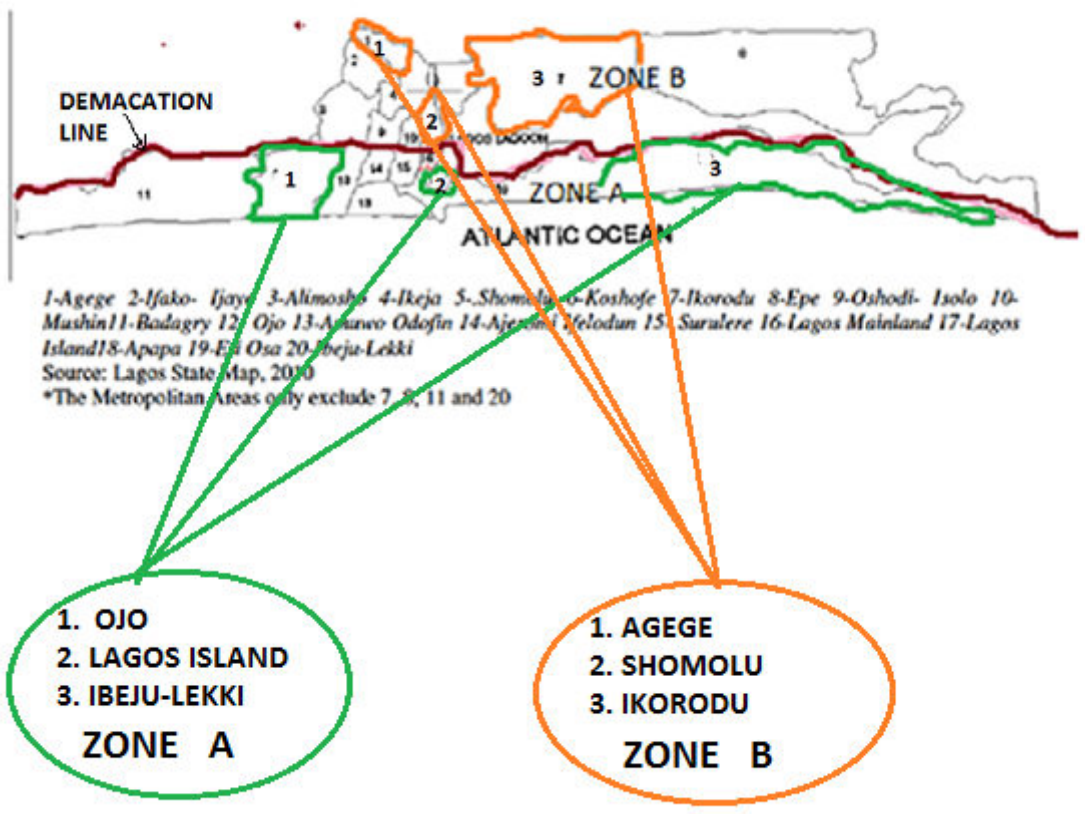

Three LGAs were randomly selected from each Zone of A and B as shown in plate3 above. The selected LGAs from Zone $A$ are as shown with green line demarcation. These are: $A_{1}$ - Ojo, $A_{2}$ - Lagos-Island and $\mathrm{A}_{3}$ - Ibeju-Lekki. The LGAs selected from Zone $\mathrm{B}$ are as shown with orange colour. These are: $\mathrm{B}_{1}-\mathrm{Agege}, \mathrm{B}_{2^{-}}$ Shomolu and $\mathrm{B}_{3}$ - Ikorodu. This gives a total of six (6) LGAs that were randomly selected from the entire twenty (20) LGAs

A total of 1.07 million residential housing stock which constitutes $10 \%$ of Nigeria housing stock is in Lagos (Oshodi, 2010). The study area has a deficit of 5million housing units which represents $27.8 \%$ of the estimated national housing deficit of 18 million in Nigeria (Oshodi, 2010). Though $1 \%$ of the average based on population could be used as sample size (Aluko, 2010), due to the large size of the entire population, a more reasonable sample size calculator derived by AMA, (2007-2012) as earlier stated was used.

A total of 384 were derived with a confidence interval of 5 as the sample size. This number was divided equally among the LGAs in each Zone to achieve equitable distribution and balance administration of the instrument. See Table1 below. This resulted in 192 sample size on each zone. This number-192 was further divided equitably among the three (3) randomly selected LGAs in each zone. This amounted to 64 sample size in each LGA as shown in Table1 below.

Table1: Sample size distribution

\begin{tabular}{|l|c|c|c|c|c|}
\hline S/No & ZONE & No LGAs/ZONE & TRZ & TRG & SUMMARY \\
\hline 1 & A & 3LGAs & 192 & 64 & 192 \\
\hline 2 & B & 3LGAs & 192 & 64 & 192 \\
\hline & & & & & 384 \\
\hline
\end{tabular}


Journal of Culture, Society and Development- An Open Access International Journal Vol.1 2013

Table2: Questionnaire distribution and percentage recovered

\begin{tabular}{|c|c|c|c|c|c|c|c|}
\hline $\mathrm{S} / \mathrm{N}$ & ZONES & LGAs & QA & QR & PRG-\% & PRZ-\% & TPR-\% \\
\hline 1 & \multirow{3}{*}{ A } & $\mathrm{A}_{1}$ & 64 & 40 & 62.5 & \multirow{3}{*}{73.96} & \multirow{6}{*}{82.6} \\
\hline 2 & & $\mathrm{~A}_{2}$ & 64 & 53 & 82.81 & & \\
\hline 3 & & $\mathrm{~A}_{3}$ & 64 & 49 & 76.56 & & \\
\hline 4 & \multirow[b]{3}{*}{ B } & $\mathrm{B}_{1}$ & 64 & 53 & 82.81 & \multirow{3}{*}{91.15} & \\
\hline 5 & & $\mathrm{~B}_{2}$ & 64 & 61 & 95.31 & & \\
\hline 6 & & $\mathrm{~B}_{3}$ & 64 & 61 & 95.31 & & \\
\hline & Total & 6 & 384 & 317 & & & \\
\hline
\end{tabular}

Table 2 above shows the distribution of questionnaires to respondents of the first target population in all the randomly selected LGAs in the two zones of the study area. In Zone A, the selected LGAs of Ojo, Lagos Island and Ibeju-Lekki as shown in Plate3, The questionnaires administered (QA) were 64 on 64 respondents in each LGAs. The questionnaires recovered $(\mathrm{QR})$ from $\mathrm{A}_{1}$ was 40 making a percentage recovered per Local Government (PRG) of 62.5. $\mathrm{A}_{2}$ has a $\mathrm{QR}$ of 53 which constitutes a PRG of 82.81percent while the $\mathrm{QR}$ of $\mathrm{A}_{3}$ was 49 making a PRG of 76.56percent. The average percentage recovered per zone (PRZ) for Zone A is 73.96.

In similar vein, in Zone B, the selected LGAs of Agege, Shomolu and Ikorodu as shown in Plate3 were administered with 64 questionnaires on 64 respondents each. The QR for $\mathrm{B}_{1}$ was 53 which constitute a PRG of 82.81percent; the $\mathrm{QR}$ from $\mathrm{B}_{2}$ was 61 which gave a PRG of 95.31percent of the number administered. $\mathrm{B}_{3}$ also had a QR of 61 resulting in a similar PRG of 95.31 percent. The average percentage of the QR for $B_{1}, B_{2}$ and $B_{3}$ is 91.15 percent which constitutes the PRZ. Out of the 384 sets of questionnaires administered on the first target population, as distributed in Table2 above, 317 were retrieved and found reasonable and good for statistical analysis. This represents a total percentage recover (TPR) of 82.6 percent of distributed questionnaires. This level of recovery is sufficient to achieve the desired result for the research. To obtain data from the practicing Architects, the list of registered architects was collected from Architects' Registration Council of Nigeria ARCON (2010). The list contains 480 names; a systematic sampling method was used to select 1 out of every 30 for the structured interview. Frequency tables and multiple regressions were run through SPSS 15.0 to obtain statistical results that was used to test the hypothesis of the research.

The hypothesis of the research is stated thus:

$H_{O}$ : The prevailing saline air does not have significant impact on the performance of paint used as external finishes at the sea side compared with the hinterland

$H_{1}$ : The prevailing saline air has significant impact on the performance of paint used as external finishes at the sea side compared with the hinterland

\subsection{DATA ANALYSIS, FINDINGS AND DISCUSSIONS}

The questionnaires administered consist of five variables. They are as stated thus: E2- How often do you carry out the repainting of the wall, D1 is saline air responsible for the rapid degradation of painted exterior in Lagos, D2- How soon after painting do you notice chalking (formation of white powder) on the wall and D8Is the exterior wall always damp. These variables according to Roy et al (1995); Morcillo (1999); Mashe and Waghoo (2004; Gonclaves et al (2009); Komshin (2010); Anderson et al (2011) are the major symptoms of painted wall under salt attack. E2 as the dependent variable was measured through D1, D2, D3 and D8 as independent variables. The structured interview contains two questions. These are: V5-How often do the buildings along the coast (Zone A) require repainting, V6-How often do the buildings at Hinterland (Zone A) require repainting.

From Table 3 below, $86 \%$ of respondents agree that saline air is responsible for the failure of paint in Zone A while $61.1 \%$ agree to thesame phenomenon in Zone B. $81.1 \%$ of the buildings in Zone A experience discolouration in the first 1-2years an average of 1.5years while 64.1 percent experience discolouration between 2-4years, an average of 3years of its existence in Zone A. The formation of white powder (chalking) on the wall develops in $83.8 \%$ of the buildings in Zone $\mathrm{A}$ in the first 1-2years an average of $1.5 y$ ears, but in Zone B, $61.1 \%$ occurrence is delayed till 2-4years of painting, an average of 3years. $90.1 \%$ of the buildings in Zone A are regularly and often damp while $72.3 \%$ of buildings in Zone B are rarely damp 
Journal of Culture, Society and Development- An Open Access International Journal Vol.1 2013

Table 3: Frequency table

\begin{tabular}{|c|c|c|c|c|c|c|c|c|c|}
\hline Location & variables & \multicolumn{8}{|c|}{ years } \\
\hline & & 1 & 2 & 3 & 4 & 5 & 6 & 7 & missing \\
\hline $\mathrm{A}$ & \multirow{2}{*}{$\begin{array}{l}\text { Is saline air responsible for rapid } \\
\text { degradation of paint in Lagos } \\
\text { (D1) }\end{array}$} & 43 & 43 & 2.8 & 9.2 & 2.1 & - & - & - \\
\hline $\mathrm{B}$ & & 10.3 & 50.9 & 4.0 & 32 & 0.6 & - & - & 2.3 \\
\hline A & \multirow{2}{*}{$\begin{array}{l}\text { How soon after painting do you } \\
\text { experience discolouration (D2) }\end{array}$} & 33.1 & 48.6 & 10.6 & 6.3 & 0.7 & - & 0.7 & \\
\hline $\mathrm{B}$ & & 13.1 & 24.6 & 20.6 & 18.9 & 12.6 & 2.9 & 4.0 & 3.4 \\
\hline A & \multirow{2}{*}{$\begin{array}{l}\text { When did you notice chalking } \\
\text { (formation of white powder) on } \\
\text { the wall(D3) }\end{array}$} & 49.3 & 34.5 & 12.0 & 1.4 & 0.7 & 0.7 & 1.4 & - \\
\hline B & & 14.3 & 21.1 & 23.4 & 16.6 & 13.1 & 0.6 & 2.9 & 8.0 \\
\hline A & \multirow{2}{*}{$\begin{array}{l}\text { How soon does the wall become } \\
\text { permanently damp (D4) }\end{array}$} & 22.5 & 67.6 & 3.5 & 4.9 & - & - & -- & 1.4 \\
\hline $\mathrm{B}$ & & 9.7 & 46.9 & 24.0 & 11.4 & & & & 8.0 \\
\hline A & \multirow{2}{*}{$\begin{array}{l}\text { How often do you carry out the } \\
\text { repainting of the wall (E2) }\end{array}$} & 9.2 & 25.4 & 42.3 & 13.4 & 8.5 & - & 1.4 & - \\
\hline B & & 10.3 & 13.7 & 21.7 & 20.0 & 19.4 & 4.0 & 4.6 & 6.3 \\
\hline
\end{tabular}

As illustrated in figure 4 below it shows that due to the action of saline air as evidenced by the symptoms of D1, D2, D3 and D4, 67.7\% of buildings in Zone A are repainted after every 2-3years forming an average of 2.5 years. $61.1 \%$ of buildings in Zone B are repainted after 3-5years stipulating an average of 4years.

Figure 4: Graphical Illustration of Tables 3

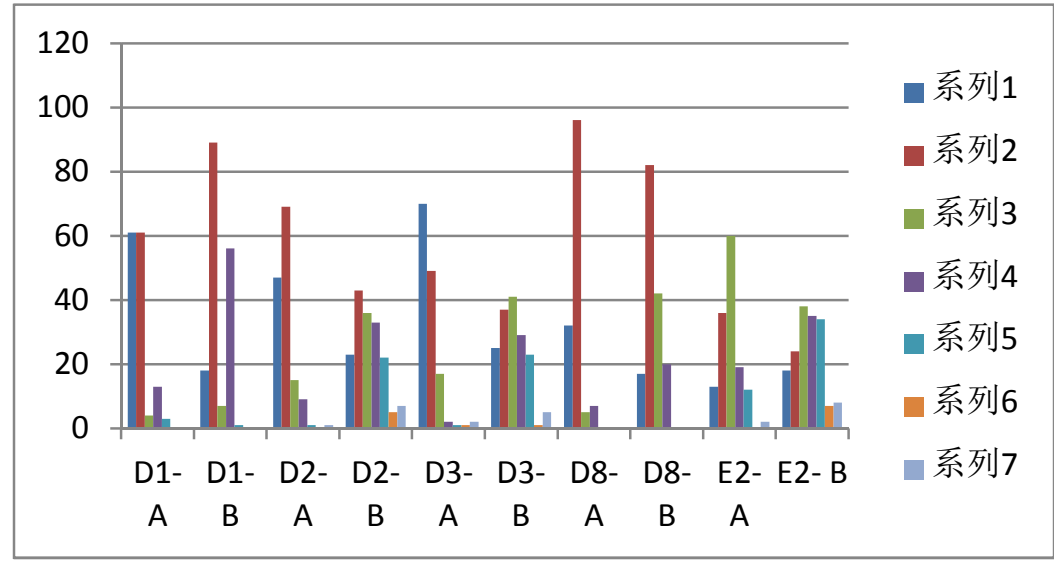

From figure 4 above, series 1-7 represents year 1-7 during which the performance of paint was measured. On the X-axis, D1 A\&B, D2 A\&B, D3A\&B, D4 A\&B and E2 A\&B are the result of the data collected on each variable for Zone A and Zone B. The figures on the $y$-axis represent the percentages of respondents. However, from the expert opinion obtained as shown in Tables 4 below, painting is required every 2 years in Zone A and 3-5years in Zone B. This brings the average number of year required for repainting in Zone A to 2years.

Table4: Expert opinion

\begin{tabular}{|l|l|l|l|l|l|}
\hline Variables & \multicolumn{4}{|c|}{ percentage } \\
\hline How often do the buildings along the coast require repainting & 1 & 2 & 3 & 4 & 5 \\
\hline How often do the buildings at hinterland require repainting & 18.8 & 50.0 & 25.0 & 6.2 & - \\
\hline
\end{tabular}

From Table 5 below, the $F$-calculated of 6.943 is higher than $F$-tabulated of 2,37 signifying that the null hypothesis $H_{O}$ is rejected and the alternate hypothesis is accepted in Zone A. Table 6 below shows an $F$ calculated of 3.689 as higher than $F$-tabulated signifying also that $H_{O}$ is rejected, however, a difference exist between the $F$-calculated for both Zones with Zone A almost having the double of Zone B because Zone A is subjected to direct saline air impact while Zone B has indirect impact. This agrees with the earlier results as shown in Tables 3 and 4 where repainting takes 2years in Zone A and 4years in Zone B

Table 5: Test of overall significance for the hypothesis $\left(\mathrm{ANOVA}^{\mathrm{C}}\right.$ )

\begin{tabular}{|c|c|c|c|c|c|c|}
\hline Location & $\begin{array}{ll}\text { Source } \\
\text { variation }\end{array}$ & $\begin{array}{l}\text { Sum of } \\
\text { Square }\end{array}$ & $\mathrm{df}$ & Mean of Square & $F$-calculated & $F$-tabulated \\
\hline \multirow{3}{*}{ Zone A } & Regression & 31.376 & 4 & 7.844 & \multirow{3}{*}{6.943} & \multirow{3}{*}{2.37} \\
\hline & Residual & 154.772 & 137 & 1.130 & & \\
\hline & Total & 186.148 & 141 & & & \\
\hline \multirow{3}{*}{ Zone B } & Regression & 31.376 & 4 & 12.034 & \multirow{3}{*}{3.689} & \multirow{3}{*}{2.37} \\
\hline & Residual & 554.573 & 170 & 3.262 & & \\
\hline & Total & 602.709 & 174 & & & \\
\hline
\end{tabular}


Journal of Culture, Society and Development- An Open Access International Journal Vol.1 2013

Table 6: Test of individual predictors for the hypothesis

\begin{tabular}{|c|c|c|c|c|}
\hline Location & Model & & $\mathrm{T}$ & Sig. \\
\hline Zone A & 1 & $\begin{array}{l}\text { (Constant) } \\
\text { D1- Is saline air responsible for the rapid } \\
\text { degradation of paint in Lagos } \\
\text { D2- How soon after painting do you experience } \\
\text { discolouration } \\
\text { D3- When did you notice chalking (formation of } \\
\text { White powder) on the wall } \\
\text { D4- Is the external wall always damp }\end{array}$ & $\begin{array}{r}18.971 \\
.068 \\
2.378 \\
-4.408 \\
-1.879 \\
\end{array}$ & $\begin{array}{l}.000 \\
.946 \\
.019 \\
.000 \\
.062 \\
\end{array}$ \\
\hline Zone B & 1 & $\begin{array}{l}\text { (Constant) } \\
\text { D1- Is saline air responsible for the rapid } \\
\text { degradation of paint in Lagos } \\
\text { D2- How soon after painting do you experience } \\
\text { discolouration } \\
\text { D3- When did you notice chalking (formation of } \\
\text { White powder) on the wall } \\
\text { D4- Is the external wall always damp }\end{array}$ & $\begin{array}{r}7.772 \\
2.076 \\
-2.794 \\
2.028 \\
-1.447 \\
\end{array}$ & $\begin{array}{l}.000 \\
.039 \\
.006 \\
.044 \\
.150\end{array}$ \\
\hline
\end{tabular}

The result in Table 6 above shows that discolouration and chalking are the predictors for the performance of paint in Zone A and Zone B while rapid degradation also predicts its performance in Zone B. Dampness is not a good predictor in both zones. Table 7 below also shows that $71.1 \%$ of E2 in Zone is as a result of D1, D2, D3 and D4 while 70.8\% of E2 in Zone B is as result of D1, D2, D3, and D4 when multiplied by $100 \%$. The closeness of the coefficient of multiple determination in both locations buttress the fact that saline negatively impact paint used as exterior finish in Lagos though the impact is more in Zone A than Zone B as expressed in the $F$-calculated and Tables 3 and 4

Table 7: Coefficient of Multiple Determination

\begin{tabular}{|ll|l|l|c|c|}
\hline Location & Model & $\mathrm{R}$ & $\mathrm{R}$ Square & Adjusted R Square & Std. Error of the Estimate \\
\hline Zone A & 1 & $.841^{\mathrm{a}}$ & .717 & .714 & 1.063 \\
\hline Zone B & 1 & $.728^{\mathrm{b}}$ & .708 & .706 & 1.806 \\
\hline
\end{tabular}

Figure 5 below shows the performance index of paint based on the findings of this research. It shows Zone $\mathrm{A}$ on the $\mathrm{x}$-axis as the zone with direct contact $(\mathrm{dSa})$ with saline air which requires repainting in 2 years average. Zone B is the zone with indirect contact (iSa) with saline air which requires repainting in 3-5years (4years average). The other parts of the tropical region that have no contact (nSa) with saline air as established by past researches such as Bliss (2006); NAHB (2000) and Roy et al (1996) require repainting in 5-7years (6years average). The calibrations of 1-7 on y-axis represent the numbers of years of the life cycle of paint.

Figure 5: Paint Performance Index. Source: Researcher's finding, 2012

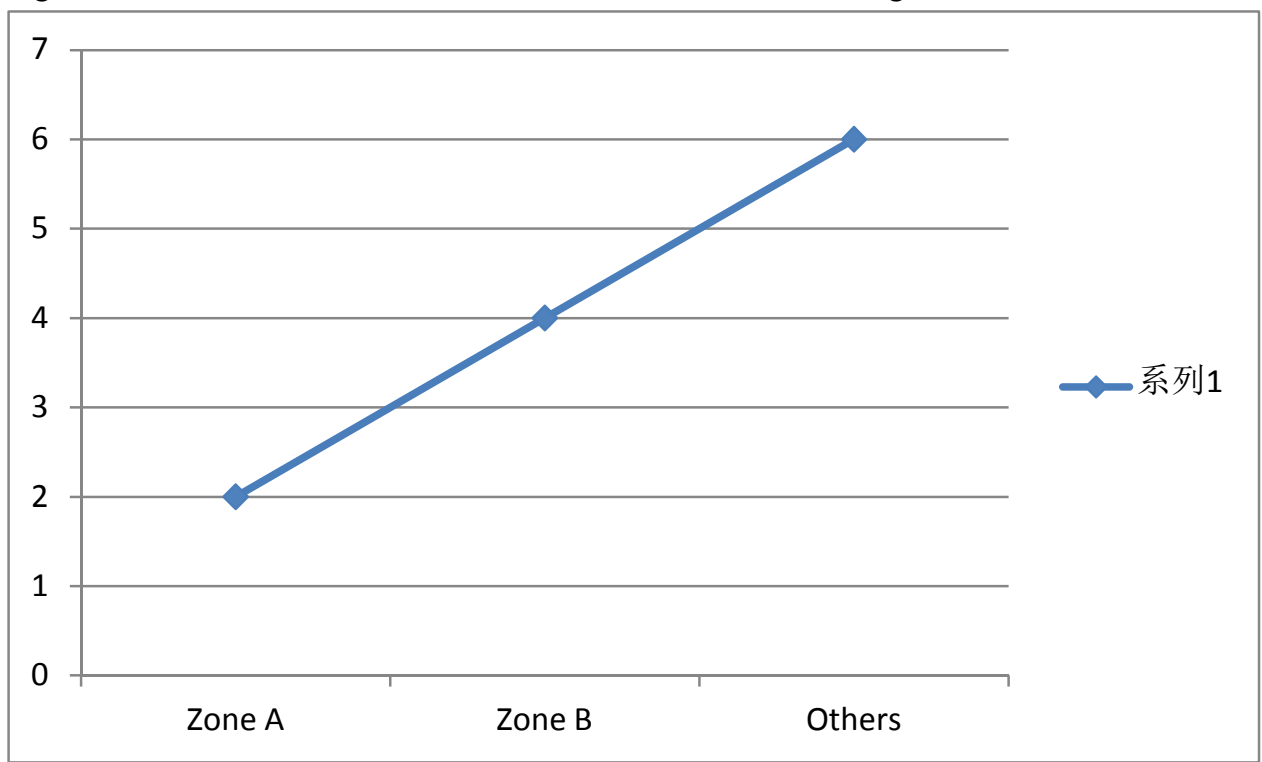

Figure 5 here

From figure 5 above, the equation for the model is derived as stated below:

$[\mathrm{Pt}+(-\mathrm{Sa})] \mathrm{d}=\mathrm{K}^{1}$

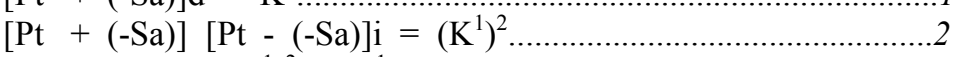

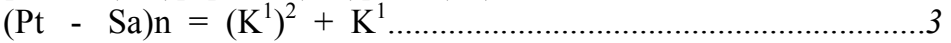


Where $\mathrm{Pt}=$ paint applied, $\mathrm{Sa}=$ saline air, $\mathrm{d}=$ Zone $\mathrm{A}, \mathrm{i}=$ Zone $\mathrm{B}, \mathrm{n}=$ others, $\mathrm{K}=2$, and each factor $=$ 1

\subsection{CONCLUSION}

Buildings in Lagos require repainting earlier than buildings in other parts of the tropical regions due to the presence of salt spray from the Atlantic Ocean. Buildings in Zone A require a period of 2years for repainting because of the close contact with the saline air from the Ocean. However, because all the sources of water in Lagos have a sizable quantity of salt (Adepelumi et al, 2009) which is used to mix paint both at production and application stage, paint applied in Zone B that is at the hinterland without close contact with the Ocean require 4years for repainting. This establishes different phenomenon for painted exterior maintenance within a single geographical location. These findings also negate and is more frequent than established maintenance requirement of paint in the tropics which studies according to Roy et al (1995); NAHB (2000); Bliss (2006) puts at 5-7years where all elements of climate are in action except saline air, salty ocean water and salty sand used for building construction.

The use of a material that requires frequent maintenance on the external surface due to climatic changes of saline air degradation will be anti-sustainable. Consideration must be given to sustainable, durable materials (Singhaputtangkul et al, 2011) which have become a global issue for an environment like Lagos.

\section{REFERENCES}

AbuBakar, B. H; Wan-Ibrahim, M. H \& Megat-Johari, M. A (2011) "A review: durability of fired clay brick mansory wall due to salt attack". Integrated Engineering, 1(2),111-127

Adepelumi, A.A; Ako, B. D; Ajayi, T. R; Afolabi, O \& Omotoso, E. J (2009) "Delineation of Saltwater Intrusion into the Freshwater Aquifer of Lekki Peninsula, Lagos, Nigeria". Environmental Geology, 56 (5), $927-933$

Ahl, J (2004) "Salt diffusion in brick structures". Material Science, 39, 4247-4254

Aluko, O. E (2010) "The impact of urbanization on housing development: the Lagos experience, Nigeria". Ethiopia journal of environmental studies and management, 3(3), 64-74

American Marketing Association (2007-2012) "Creative research systems, the survey system-sample size calculator". Available at: http://www.surveysystem.com/sscal.htm (accessed 10 March 2012)

Anderson, B; Frisvad, J. C; Sondergaad, Ib; Rasmussen, Ib \& Larsen L. S (2011) "Associations between fungai species and water-damaged building materials". Applied and Environmental Microbiology, 77(12), 4180-4189.

ARCON Register (2010) Register of Architectural Firms entitled to practice in Nigeria. CAP 20 Laws of the Federal Republic of Nigeria (Decree 10 of 1969 as amended) $2^{\text {nd }}$ Edition. Iduma Press, Lagos

Baltrenas, P; Kazlauskiene, A \& Zaveckyte, J (2006) "Experimental investigation into toxic impact of road maintenance salt on grass vegetation". Environmental Engineering and Landscape Management, 14(2), $83-88$

Bate, S. J (2002) A critical evaluation of salt weathering impacts on building materials at Jazirat al Hamra. Oxford Brookes University, UAE.

Bliss, S (2006) Best practices guide to residential construction: materials, finishes and details. John Willey \& Sons, New York

Butch, A (2008) "Salt water corrosion effects on concrete. David Hall Building appraisals", available at: http://www.buildingdefects.co.au (accessed 1 November 2011

Butt, T. E; Umeadi, B. B. N and Jones, K. G (2010) "Sustainable development and climate change induced obsolescence in the built environment", available at: http:// kadisnt.hku.hk (accessed 15 August 2011)

Corvo, F; Reyes, J; Valdes, C; Villasenor, F; Cuesta, O; Aguilar, D \& Quintana, P (2010) "Influence of air pollution and humidity on limestone materials degradation in historical buildings located in cities under tropical coastal climates". Water Air Soil Pollution, 205, 359-375

Costal, A \& Appleton, J (1999) "Chloride penetration into concrete in marine environment- part I: main parameters affecting chloride penetration". Materials and Structures, 32, 252-259

Creswell, J. W (2012) Educational research; planning, conducting and evaluating quantitative and qualitative research, Fourth Edition. Pearson Education, Boston, MA

David, H (2008) "Building Defects". Australia, Amazing .com press, available at: http://www.buildingdefects.co.au (accessed 8 October 2011)

Esubiyi, A. O (1994) Obsolescent and Real Property Values: A Case Study of Lagos. Unpublished B.Sc. Dissertation, Department of Estate Management, Obafemi Awolowo University, Ile Ife, Nigeria.

Folorunsho, A. R (2004) Environmental consequences of meteorological factors affecting ocean dynamics along gulf of Guinea coast. Unpublished PhD thesis, University of Lagos, Nigeria.

Folorunso, C. O (2010,) "Impervious building (coating) material's workability in southwest Nigeria: a case of Akure, Ondo State". Proceedings of 3rd West Africa Built Environment Research (WABER) July 27-28, 
2010, Accra, Ghana

Goncalves, T. D; Pel, L \& Rodrigues, J. D (2009) "Influence of Paints on Drying and Salt Distribution Processes in Porous Building Materials". Construction and Building Materials, 23, 1751-1759

Groot, C; Vanhees, R \& Wijffels, T (2009) "Selection of plasters and renders for salt laden mansory substrates. Construction and Building Materials", 23, 1743-1750

Kaufman, M (2003) “Ocean Salt is said to Signal Climate Change”. Milwaukee Journal Sentinel, 1(1), 8-15.

Komshin, A. S (2010) "Mathematical modelling of the process of measurement control of the degradation of construction materials. Measurement Techniques", 53(9), 976-982

Leedy, P. D \& Ormrod, J. E (2010) Practical Research-. Planning and Research. Merill Publishers, Princeton.

Malshe, V. C \& Waghoo, G (2004) "Weathering Study of Epoxy Paints". Progress in Organic Coatings, 51, 267-272.

Morcillo, M (1999) "Soluble Salts: Their Effect on Premature Degradation of Anticorrosive Paints". Progress in Organic Coatings, 36, 137-147

Mukhopadhuyaya, P; Batcheller, D; Kumaran, M. K; Lackey, J.C; Van Reenan, D \& Normandin, N (2011) "Correlation between water vapour and air permeability of building materials: experimental observations". ASTM International, 8(3), pp1-14

NAHB (2000) "National Association of home Builders: Life expectancy of home components. US Department of Housing and Urban Development Residential Rehabilitation Inspection Guide 2000", available at: http://www.oldhouse.com (accessed 15 August 2011)

Navarro, C. R \& Doehne, E (1999) "Salt weathering: influence of evaporation rate, supersaturation and crystallization pattern". Earth Surface Processes and Landforms, 24, 191-209

Oshodi, L (2010) "Housing population and development in Lagos, Nigeria". Housing, Environment and Urban Planning, 12(3), .54-59

Oyewo, E. O; Ajao, E. A \& Orekoya, T (1982) Seasonal variations in surface temperature and salinity around Lagos Harbour, Nigeria. Technical Paper number 10, Nigerian Institute of Oceanography \& Marine Research, Lagos.

Roy, S. K; Thye, L. B \& Northwood, D. O (1995) "The Evaluation of Paint Performance for Exterior Applications in Singapore's Tropical Environment". Building and Environment, 31(5), 477-486.

Sawdy, A \& Heritage, A (2007) "Evaluating the influence of mixture composition on the kinetics of salt damage in wall paintings using time lapse video imaging with direct data annotation". Environmental Geology, $52,303-315$

Scherer, G. W (2004) "Stress from crystallization of salt". Cement and Concrete Research, 34, 1613-1624

Singhaputtagkul, N; Low, S. P \& Teo, A. L (2011) "Integrating sustainability and buildability requirements in building envelope". Facilities, 29(5\&6), 255-267

Vanhees, R. P. J; Naldini, S \& Roddriques, J. D (2009) "Plasters and renders for salt laden substrates". Construction and Building Materials, 23, 1714-1718

Wellman, H \& Wilson, W (1965) "Salt weathering, a neglected geological erosive agent in coastal and arid environments". Nature, 8, 1097-1098

Young, D (1995) "Rising damp and salt attack". Department of Environmental and Natural Resources, Australia available at: http://www.supergreenme.com/ (accessed 10 October 2011)

Zahn, R (2007) "Salty oceans provide early warning for climate change". University of Barcelona, Edific B. Spain, 34(3), 5-6

Zhang, Y; Wang, Q. C; Jia, L \& Huo, L (2011) “A similarity model design in concrete attacked by sulfate erosion”. Advance Material Research, 374-377, 2379-2383 